\title{
Intelligent System for the Management of Resources Dedicated to Humanity
}

\author{
${ }^{1}$ S. Chouya, ${ }^{2}$ S. Bourekkadi, ${ }^{3}$ S. Khoulji, ${ }^{4}$ K. Slimani, ${ }^{5}$ M.L. Kerkeb, \\ 1,2,3,5 Laboratory Information system engineering, \\ ABDELMALEK ESSAADI University, National School of Applied Sciences, Tetouan, Morocco. \\ ${ }^{4}$ Faculty of Sciences, Ibn Tofail University, Kenitra, Morocco \\ chouya.saad@gmail.com, sisalmane@gmail.com,khouljisamira@gmail.com; slimani.uit@gmail.com, \\ kerkenml@gmail.com, acmlis.conference@gmail.com
}

\begin{abstract}
Our work consists, one way or another, in projecting the light on the intensive need for the reasonable management of water resources. According to the latest studies and statistics, Morocco will soon face a serious crisis if it has not taken the necessary precautions and decisions to deal with the dangers linked to water resources.

The solution we have developed is not costly at the material / financial level, since it does not imply to the client to have a smartphone or an internet connection, but precisely the possession of the client or other members Of his family of a mobile phone of whatever nature. From this we can assume that our solution adopts the communication network technology of mobile phones without imposing exclusivity on a company without others and that will be totally free.

Among the positive results that our work will bring is the creation of an atmosphere of relaxation and satisfaction among the citizens, through continuous communication and interaction with them, to make them more satisfied with the quality of services. Moreover, this solution is one of the policies that call for the preservation of water resources and the restoration of citizens' confidence in drinking water companies, and on the other hand we will contribute to the positif use of Technology and modern means of communication, and the humanization of our information systems.

To conclude, we believe that these ideas will have a favorable influence on all poles, whether citizens, countries or future generations.

Keywords: Water, Decision-making system, Water ressources, Humanization.

\section{Introduction}

Morocco, like virtually the entire world, suffers from a threat to its stability and viability. This problem manifests itself in a remarkable decrease in water resources and in its poor management, which puts us face to face with the Problem: how can we fight against the waste of water, and the irresponsible management of this vital element?
\end{abstract}


S. Chouya, S. Bourekkadi, S. Khoulji, K. Slimani, M.L. Kerkeb,. Intelligent System for the Management of Resources Dedicated to Humanity. Transactions on Machine Learning and Artificial Intelligence, Vol 5 No 4 August (2017); p: 683-688

Current research and studies on water resources indicate that the dangers associated with this issue need to be targeted and that this threat needs to be unified in order to address this threat through the use of all possible means can help streamline water use.

Morocco has committed itself on a strategy aimed at preserving water resources, among the methods that the state has to adopt in this respect, is the policy of construction of the dams which was considered among the political wise ones, the sensitization of the Citizens to better water management with written, visual and audiovisual supports.

As researchers in the field of computing and development, we must engage in this noble cause that seeks to ensure a decent existence and fair and equitable sharing of this "water" wealth.

Among the barriers to our work is the insufficient data on the rate of water consumption per house, since the water company concerned refuses to collaborate or answer our questions. On the other hand, some citizens provided us all the data and information on their monthly water consumption. In addition, scientific research in this area was unavailable and insufficient or inaccessible, which forces us to multiply our efforts to make it happen.

The implementation of our solution is not costly and does not require much effort from water supply companies or citizens. While our solution will pay dividends and benefits to all participants, it will prevent it from falling into these accidents and clashes between customers and water supply companies, taking what's going in Tangier as an example.

\section{Information systems are needed}

Man has become possessed and enslaved to computer systems, since these systems help man to perform several tasks and professional or personal activities, man uses this effective tool to perform the least tasks. Now, the time has come to engage these information systems to control our water consumption and correct some unacceptable behavior in order to move us towards the right path, one that will guarantee the next generations a decent existence and will save the Money that can be used in other things and in other fields, instead of spending them to pay for costly water consumption bills, which causes the citizens to suffer.

The above clearly shows that the information systems if well used, they become an indispensable asset to promote security and stability and serve humanity.

\section{The need for governance of water resources management}

- Good vision

- Specification of obligations

- $\quad$ Specification of duties

- Responsibility of organizer /citizen

- Harmonization and coherence to establish public interest

- The right intervention

We are convinced that all of the above aims to create a collective consciousness that affects citizens a priori, on the need to invest our efforts and our skills to preserve water and the achievement of objectives while minimizing costs as much as possible. 


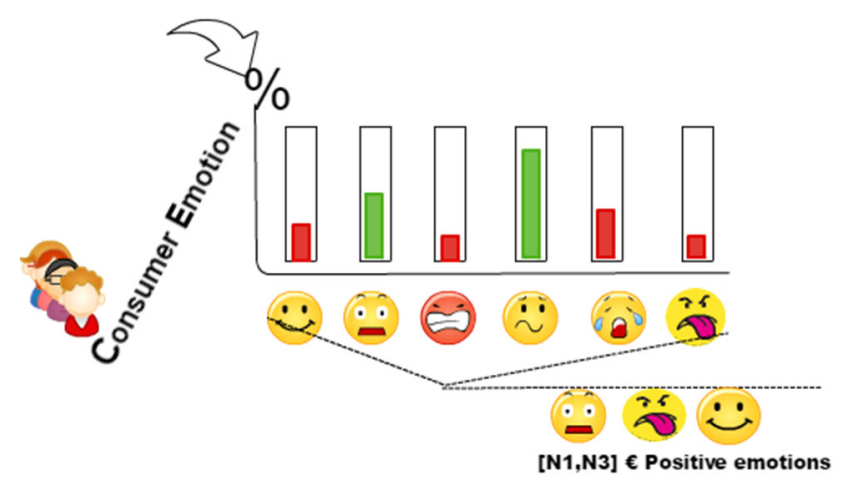

Figure 21 Consumer Emotion

\section{Proposition and results}

An intelligent information system seems to be an adequate and effective solution that will bring its benefits, since half of the citizens we have questioned have confirmed that such a solution will be a positive step towards creating an atmosphere of satisfaction And trust since they will be informed of the details of the rate of their consumption before the arrival of the bill, which will limit any kind of complication and complaint.

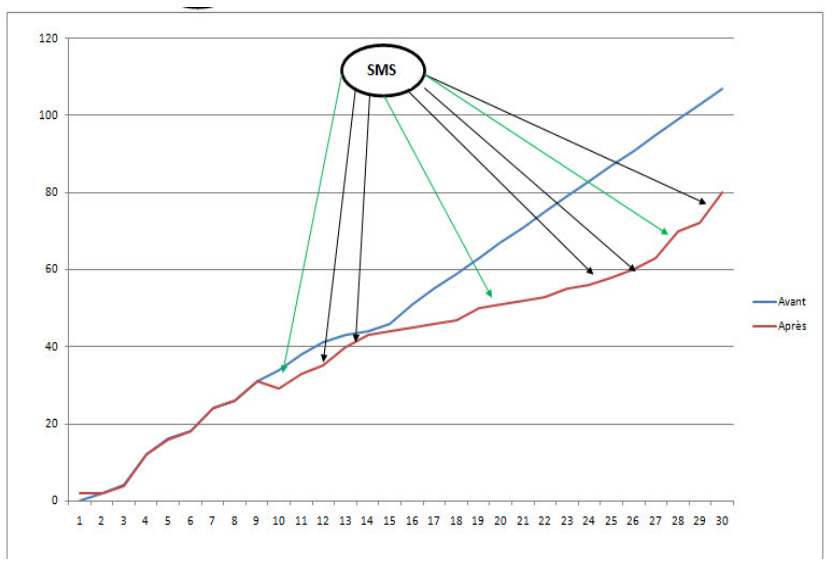

Figure 22 Consumption before and after using our solution

\section{Design and architecture of proposed information system}

At the level of the user's diagram design, the system has four factors, the information system manager, who decides the customer's need through the intermediary call center, this second factor makes the customer relationship management, The third factor is the technician, that is charged for the development and the improvement of the system, finally the customer the fourth factor, we can even consider it the core of the application. See the figure below which explains in brief the tasks that each factor can do, also the links between these factors. 
S. Chouya, S. Bourekkadi, S. Khoulji, K. Slimani, M.L. Kerkeb,. Intelligent System for the Management of Resources Dedicated to Humanity. Transactions on Machine Learning and Artificial Intelligence, Vol 5 No 4 August

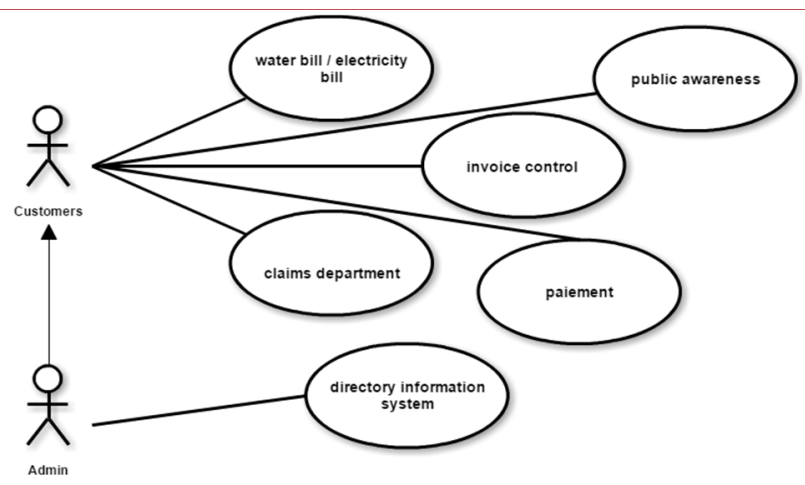

Figure 23 Use Case Diagram

The system will allow its user to perform several tasks, such as consultation of water and electricity bills, online payment of these bills, communication with the call center of the Drinking water and electricity distribution company, file applications and complaints, follow up on individual consumption, as it can also enjoy the e-documents "electronic documents" space without being forced to move to the agency.

Also note that the system is able to sensitize and train customers on the management of water resources and electricity, an adaptive awareness with each type of customers (home consumption, Hotel, company ...) see the figur below that presents a simple architecture of the presented system.

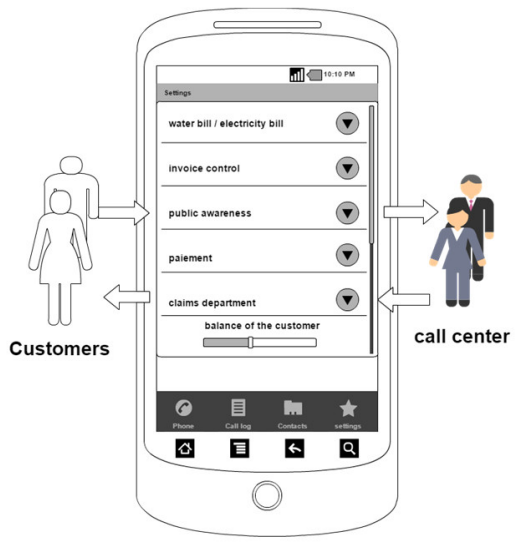

Figure 24 Common Platform of Communication

\section{Discussion}

We propose a set of algorithmic tools to guarantee - before its deployment - that an application, once installed on a machine, will be able to have a level of humanized communication with its user avoiding the maximum of any source of client dissatisfaction.

Today, it is recognized that new information and communication technologies (ICTs) play an important role in supporting and ensuring the majority of activities carried out within a company, particularly in the field The management of the resources attached to man, which is the object of the continuity of this modest work.

To meet these needs, we rely on the concepts of the man-machine relationship; Our next task is to provide an applicable and realistic solution in the northern region of Morocco. 


\section{Conclusion}

Water is the symbol of life and fertility, it is indispensable, No living being on planet Earth can survive without it. It is used by both humans and ecosystems throughout their cycles. Water is the main constituent of our body, A human being is composed of more than two thirds of water, and a loss of more than $15 \%$ of our water can cause dehydration and death. Starting from this observation, water is even sought on Mars, and through its explorations Man seeks to know if he is alone in the universe. This may not be the case, but what remains certain is that man is alone in the face of his responsibilities.

\section{ACKNOWLEDGEMENTS}

We would like to express our appreciation to Prof. Dr S.Khoulji and M.L.KERKEB for their great encouragement, moral supports and their guidance, without their valuable assistance, this work would not have been completed.

The authors would also like to address special thanks to JOURANI MOHAMED and ALI BOUAZZAZ for their assistance with particular technique, and for their comments that greatly improved the manuscript.

This research was supported by the grant of National Center for Scientific and Technical Research (CNRSTMorocco): No. 6UAE2015 and 757UIT for the first and the third authors.

\section{REFERENCES}

[1] E.B. Foa \& E. Meadows, « Psychosocial treatments for posttraumatic stress disorder: A critical review », Annual Review of Psychology, 48: 449-480, 1997.

[2] S.Bourekkadi, S.Khoulji, M.L.Kerkeb ,A.Mabrouk "psychologie informatique et son impact sur le comportement humain" International Journal of Innovation and Applied Studies, vol. 14 No. 2 Jan. 2016, pp. 543- 548.

[3] KAMATE, M. Z. Etude des troubles psychiatriques chez les emigres dans le service de psychiatrie du chu point «G». 2009.

[4] Sebastiani, F. Machine learning in automated text categorization. ACM computing surveys (CSUR), 34(1), 1-47. 2002.

[5] Howell, D., Bestgen, Y., Yzerbyt, V., \& Rogier, M. Méthodes statistiques en sciences humaines. 2008.

[6] Stafford, J., \& Bodson, P. L'analyse multivariée avec SPSS. Puq. 2006.

[7] K.Slimani,S.Bourekkadi, R.Messoussi, S.Khoulji, N.Bezad, M.L.Kerkeb “Design of an Awareness System on Sexual and Reproductive Health Based on the Recognition of Emotional Facial Expressions", International Journal on Recent and Innovation Trends in Computing and Communication (IJRITCC), March 16 Volume 4 Issue 3 , ISSN: 2321-8169, PP: 193 - 196.

[8] Skinner, E. A., \& Belmont, M. J. Motivation in the classroom: Reciprocal effects of teacher behavior and student engagement across the school year. Journal of educational psychology, 85(4), 571.1993. 
S. Chouya, S. Bourekkadi, S. Khoulji, K. Slimani, M.L. Kerkeb,. Intelligent System for the Management of Resources Dedicated to Humanity. Transactions on Machine Learning and Artificial Intelligence, Vol 5 No 4 August (2017); p: 683-688

[9] Day M, Semrad EV. Schizophrenic reactions. In : Nicholi Jr AM (Ed.) The Harvard Guide to Modern Psychiatry. Cambridge, Mass: Belknap Press of Harvard University Press; 1978. p. 199-241.

[10] Goodenow, C. The psychological sense of school membership among adolescents: Scale development and educational correlates. Psychology in the Schools, 30(1), 79-90. 1993.

[11] Kandel, E. R. Un nouveau cadre conceptuel de travail pour la psychiatrie. L'Evolution psychiatrique, 67(1), 12-39. 2002.

[12] Allais, M. La psychologie de l'homme rationnel devant le risque: la théorie et l'expérience. Journal de la Société de Statistique de Paris, 94, 47-73. 1953.

[13] Michel Volle, Analyse des données, Economica, 4e édition, 1997 (ISBN 2717832122)

[14] Kahana RJ. Psychotherapy: models of the essential skill. In : Bibring GL (Ed.) The Teaching of Dynamic Psychiatry : A Reappraisal of the Goals and Techniques in the Teaching of Psychoanalytic Psychiatry. Madison, Conn: International Universities Press; 1968. p. 87-103.

[15] De Castro, L. N., \& Timmis, J. Artificial immune systems: a new computational intelligence approach. Springer Science \& Business Media. 2002.

[16] Schwartz JH, Kandel ER. Modulation of synaptic transmission: second-messenger systems. In: Kandel ER, Schwartz JH, Jessell TM (Eds.) Essentials of Neural Science and Behavior. East Norwalk, Conn: Appleton \& Lange; 1995. p. 243-67.

[17] Giorgio Conti et Carlo Perelli, "Governing tourism monoculture: Mediterranean mass tourism destination and governance networks", dans Peter M. Burns et Marina Novelli (dir.), Tourism and Politics. Global Framework and Local Realities, Elsevier, 2007.

[18] Turban, E., Aronson, J., \& Liang, T. P. Decision Support Systems and Intelligent Systems 7 “”' Edition (pp. 10-15). Pearson Prentice Hall. 2005.

[19] Roy, N., \& Garon, R. Hors thème Étude comparative des logiciels d'aide à l'analyse de données qualitatives: de l'approche automatique à l'approche manuelle. Recherches qualitatives, 154. 2013.

[20] Wanlin, P. L'analyse de contenu comme méthode d'analyse qualitative d'entretiens: une comparaison entre les traitements manuels et l'utilisation de logiciels. Recherches qualitatives, 3, 243-272. 2007.

[21] Benzécri, J. P. L'analyse des données (Vol. 2, p. I). Paris: Dunod. 1973.

[22] Tiberghien, G., \& Beauvois, J. L. Domination et impérialisme en psychologie. Psychologie française, 53(2), 135155. 2008.

[23] Bergadaà, M. Le temps et le comportement de l'individu Deuxième partie. Recherche et Applications en Marketing, 4(1), 37-55. 1989. 